\title{
Natural forest colonisation and soil formation on ash dump in southern taiga
}

\author{
Olga Nekrasova ${ }^{1} \bowtie$, Tatiana Radchenko ${ }^{1}$, Elena Filimonova ${ }^{1}$, Natalia Lukina $^{1}$, \\ Margarita Glazyrina ${ }^{1}$, Maria Dergacheva ${ }^{2}$, Anton Uchaev ${ }^{1}$, Anna Betekhtina ${ }^{1}$ \\ ${ }^{1}$ Ural Federal University, Ekaterinburg, Mira Av. 19, Ekaterinburg 620002, Russia, e-mail: o_nekr@mail.ru \\ ${ }^{2}$ Institute of Soil Science and Agrochemistry SB RAS, Lavrentieva 8/2, Novosibirsk 630090, Russia
}

\begin{abstract}
Ash dumps occupy significant areas around the world and make a negative influence on the environment. This effect is decreased by their natural colonisation determined by the bioclimatic conditions of the area. The purpose of the current study was to identify the structure of the forest communities and the initial stages of soil formation on the ash dump in southern taiga.

This study was carried out on three sites in the forest phytocoenosis formed in the process of revegetation of the Verkhniy Tagil Power Station ash dump over 50 years, as well as on two background forest sites in the Middle Urals. Complex geobotanical and soil studies were carried out.

The results of the study show that forest phytocoenoses with a predominance of hardwood species (Betula pendula Roth and Populus tremula L.) and a small admixture of coniferous species can form on the non-recultivated ash dump within 50 years in a boreal zone. In total, the studied mixed forest phytocoenoses are similar in composition to zonal secondary forests, but differ by having lower height and diameter of the stand, as well as herb-shrub layer coverage. Their species density and floristic richness are also lesser. The study proved that the process of soil formation is also proceeding according to the zonal type in the ash substrate under forest communities. The results of the study can be applied to justifying the forecasts of ecosystem restoration on the technogenic substrate, as well as for the species selecting for their recultivation in the studied area and similar to it.
\end{abstract}

\section{KeY WORDS}

ash dump, ash substrate, forest community, natural colonisation, southern taiga, Technosols

\section{INTRODUCTION}

Ash dumps that occupy huge areas in the world have extremely adverse environmental effects, acting as air and water pollutants. In some cases (a favourable position in the geomorphological profile, the leeward side, remoteness from settlements, etc.), ash dumps are left under natural colonisation, resulting in the forest community formation in a boreal zone. The vegetation formed on ash dumps positively affects the processes of soil for- 
mation, reducing the migration of silty ash particles and improving the physicochemical properties of the technogenic substrate.

A number of publications are devoted to the characteristics of natural successions on a technogenic substrate (Chu 2008; Pandey et al. 2012, 2014; Pandey 2015; Pandey and Prakash 2015; Mustafa et al. 2012; Mitrovic et al. 2012; Pandey and Bajpai 2016; Chibrik et al. 2016) and directly to the substrate properties (Jambhulkar and Juwarkar 2009; Pandey and Singh 2014; Shaheen et al. 2014; Weber et al. 2015; Uzarowicz et al. 2017, 2018; Gajic et al. 2018). However, predicting the formation of various ecosystems on technogenic substrates and establishing patterns in substrate property changes, as well as the selection of local flora species for recultivation, require the study of natural successions and substrate properties in the most diverse bioclimatic conditions.

The purpose of this study is to identify the features of the structure of forest communities formed on the ash dump during natural colonisation within 50 years and the initial stages of soil formation by them in southern taiga.

\section{Material AND MEthods}

The work was performed on the ash dump of Verkhniy Tagil Power Station (VTPS) in the Sverdlovsk region $\left(57^{\circ} 20^{\prime} \mathrm{N}\right.$ and $\left.59^{\circ} 56^{\prime} \mathrm{E}\right)$ on the eastern macroslope of the Middle Urals (Fig. 1). The ash dump formed by brown coal ash occupies $1.25 \mathrm{~km}^{2}$. After the end of dumping

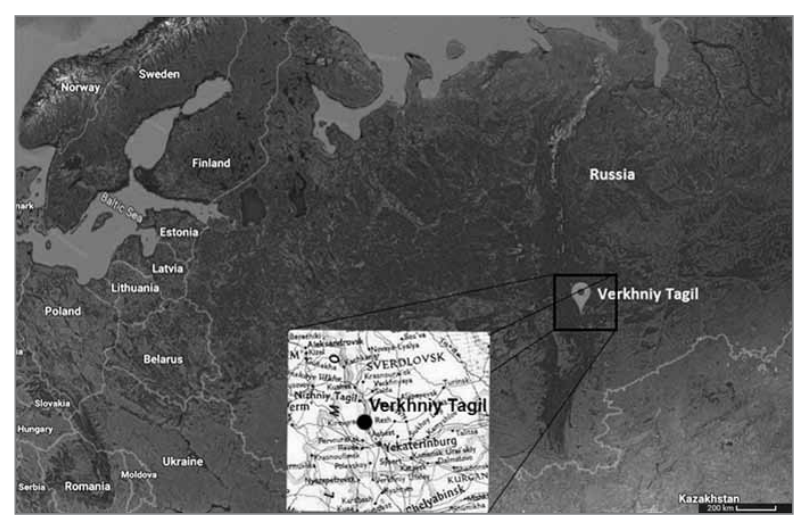

Figure 1. Location of the study object (in 1968-1970), part of the ash dump territory was left under natural colonisation.

The territory under study belongs to the Middle Urals southern taiga province and is characterised as moderately cold in terms of heat supply and over-humidified in terms of moisture availability: the average annual temperature is $1.9^{\circ} \mathrm{C}$, the sum of temperatures more than $10^{\circ} \mathrm{C}$ is equal to $1600^{\circ} \mathrm{C}$, the annual precipitation is near $570 \mathrm{~mm}$ and the hydrothermal coefficient is about 1.5 (National atlas of Russia 2008). Indigenous vegetation is represented by southern taiga pine forests and by pine-spruce forests in some cases; secondary birch and mixed birch-pine forests are found less often (Shakirov 2011).

Forest phytocoenosis formed in the process of natural colonisation of the VTPS ash dump, filling of which was stopped 50 years ago, was the object of our investigation. Three typical forest sites were identified, where complex geobotanical and soil studies were carried out. Two background forest sites were used as control at a distance of 3-7 km from the ash dump.

The area of geobotanical description on each site was $250-300 \mathrm{~m}^{2}$. The species composition, crown density, and height and trunk diameter at $1.3 \mathrm{~m}$ were taken into account when describing the tree layer, all individuals of each species were counted and young growth and self-sown tree species were recorded. The projective cover, height and composition of shrub layer, herb-shrub layer and moss-lichen cover were determined.

Fifty of Raunkier's plots $\left(\mathrm{S}=0.25 \mathrm{~m}^{2}\right)$ were laid at each site to characterise the herb-shrub layer. Floristic lists with an assessment of each species' abundance were made using Drude scale converted into expert assessment. The class of species constancy was determined (I - occurrence $0-10 \%$; II - 11-20\%; III - 21-30\%; IV - 31-40\%; V - 41-50\%; VI - 51-60\%; VII - 61-70\%; VIII - 71-80\%; IX - 81-90\%; $\mathrm{X}-91-100 \%$ ), as well as species saturation on an area of $0.25 \mathrm{~m}^{2}$. The dominant species were identified based on the assessment of projective cover and phytomass stocks.

Similarity in species composition between communities was calculated by Sorensen's coefficient of community similarity (Ks) (Smith and Smith 2012):

$$
\mathrm{Ks}=2 \mathrm{C} /(\mathrm{S} 1+\mathrm{S} 2)
$$


where:

$\mathrm{C}$ - the number of similar species in both the habitats,

$\mathrm{S} 1$ - the number of species of the first site,

$\mathrm{S} 2$ - the number of species of the second site.

Soil sections and their morphological descriptions were done in each ash dump site and each control site. Samples were taken from each soil horizon distinguished; additional sampling was done from a depth of $40-50 \mathrm{~cm}$ of ash dump. The main physicochemical characteristics of the ash substrate and soils were determined by the conventional methods of Russian paedology (Arinushkina 1970; Vorobyova 2006). Particle size distribution was determined by the pipette method, total organic carbon (TOC) by the Tjurin's method and total nitrogen $(\mathrm{N})$ by the Kjeldahl's method with spectrophotometric termination. The $\mathrm{pH}$ was analysed potentiometrically, available potassium $\left(\mathrm{K}_{2} \mathrm{O}\right)$ by flame emission and available phosphorus $\left(\mathrm{P}_{2} \mathrm{O}_{5}\right)$ by spectrophotometry. Exchangeable $\mathrm{Ca}^{2+}$ and $\mathrm{Mg}^{2+}$ were detected by titration.

\section{Results}

\section{Characteristics of ash dump vegetation}

During the period since the conservation of the VTPS ash dump, its wet, non-recultivated sites were firstly colonised by the short-term pioneer group of halophyte species (Puccinellia distans (Jacq.) Parl. and Puccinellia hauptiana V. Krecz), which was replaced by a shrub group and later on, natural colonisation by trees had started (Chibrik et al. 2016). A brief description of the studied forest communities formed in these sites of the ash dump is given in Table 1.

Five species of trees were identified in the forest community of Site 1. Populus tremula L. and Betula pendula Roth dominated in the upper tree layer; their crown density was 0.6 . The trees had an average height of $16.4 \mathrm{~m}$ (ranging from 13 to $18 \mathrm{~m}$ ) and an average stem diameter of $13.1 \mathrm{~cm}$ (from 8.5 to $20.0 \mathrm{~cm}$ ). The second layer was not formed; there were only single individuals with height 4-9 m (Betula pubescens Ehrh., Pinus sylvestris $\mathrm{L}$. and Picea obovata Ledeb). The composition of Site 1 stand was the following: Po. tremula (54\%), B. pendula (31\%), Pin. sylvestris $(9 \%)$, B. pubescens $(3 \%)$ and Pic. obovata (3\%).

Table 1. Characteristics of phytocoenoses

\begin{tabular}{|c|c|c|c|c|c|}
\hline \multirow{2}{*}{ Characteristic } & \multicolumn{3}{|c|}{ Ash dump } & \multicolumn{2}{|c|}{ Control } \\
\hline & site 1 & site 2 & site 3 & control 1 & control 2 \\
\hline \multicolumn{6}{|c|}{ Forest stand } \\
\hline Tree age, years & $35-40$ & $35-40$ & $35-40$ & $80-90$ & $90-100$ \\
\hline Crown density & 0.6 & $0.4-0.5$ & $0.4-0.5$ & $0.5-0.6$ & $0.4-0.6$ \\
\hline First layer height, $\mathrm{m}$ & $13-18$ & $12-16$ & $12.5-17$ & $16-24$ & $16-25$ \\
\hline First layer stem diameter, cm & $8.5-20.0$ & $7.0-20.0$ & $9.0-19.0$ & $14.0-26.0$ & $14.5-30.0$ \\
\hline Second layer height, $\mathrm{m}$ & $4-9$ & $4.5-10.5$ & $4-12$ & $5.5-12$ & $6-12$ \\
\hline Second layer stem diameter, cm & $3.0-8.5$ & $3.0-6.0$ & $2.5-10.0$ & $4.0-10.0$ & $5.5-12.5$ \\
\hline \multicolumn{6}{|c|}{ Young growth and self-sown tree species } \\
\hline Young growth height, m & $0.1-3.0$ & $0.1-3.5$ & $0.1-3.8$ & $0.1-5.0$ & $0.1-5.5$ \\
\hline Total number per hectare & 2300 & 2700 & 2900 & 1900 & 1500 \\
\hline \multicolumn{6}{|c|}{ Shrub layer } \\
\hline Projective cover, $\%$ & 10 & $25-30$ & 5 & 20 & $25-30$ \\
\hline Average height, $\mathrm{m}$ & 0.8 & $0.6-2.5$ & 2.2 & $0.8-4$ & $0.8-4$ \\
\hline \multicolumn{6}{|c|}{ Ground layer } \\
\hline Herb-shrub layer cover, $\%$ & $5-45$ & $15-50$ & $15-55$ & $65-85$ & $80-95$ \\
\hline Herb-shrub layer height, cm & $15-30$ & $20-33$ & $25-40$ & $40-65$ & $50-85$ \\
\hline Moss-lichen layer cover, $\%$ & 5 & 5 & - & 25 & 35 \\
\hline
\end{tabular}


The total number of young growth and self-sown trees was 2300 individuals per hectare; aspen seedlings dominated (46\%). The composition of the young growth is shown in Figure 2.

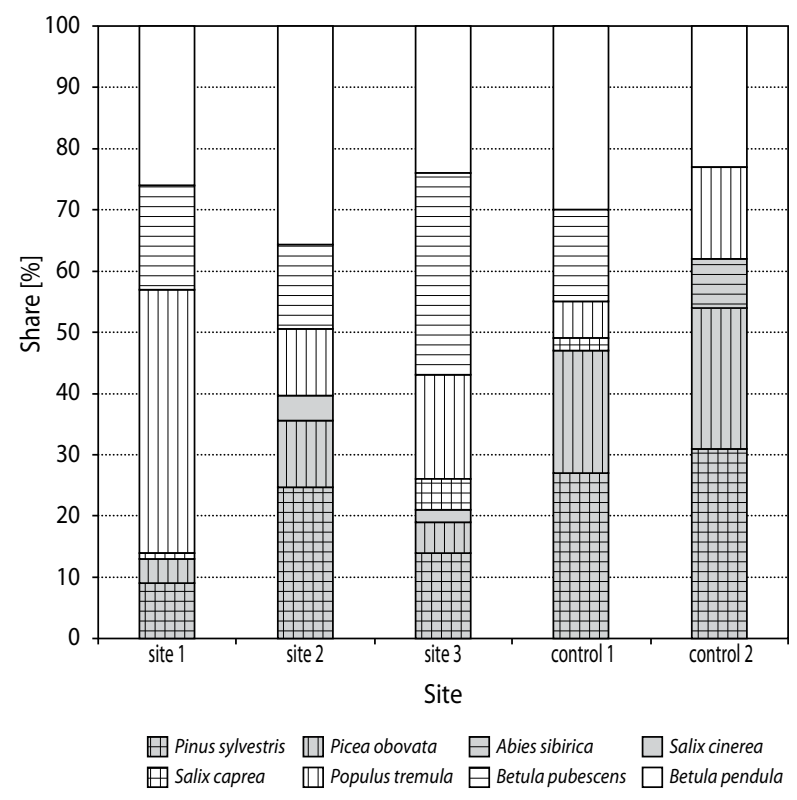

Figure 2. The structure of young growth and self-sown trees of forest communities

The layer of young growth in Site 1 was formed weakly (its projective cover was $10 \%$ ) and was represented by six species of shrubs. The height of Chamaecytisus ruthenicus (Fisch. ex Woloszczak) Klask., Rosa acicularis Lindl. and Rosa majalis Herrm. reached $0.8 \mathrm{~m}$; self-sown species of So. aucuparia L., Padus avium Mill. and Viburnum opulus L. were $0.1-0.4 \mathrm{~m}$ in height.

Thirty-five species of plants were identified in the herb-shrub layer; its projective cover was uneven from $5 \%$ to $45 \%$, averaging $30 \%$. The species found had the following constancy: VII - Poa pratensis L., Amoria repens; VI - Alchemilla vulgaris L., Deschampsia cespitosa (L.) P. Beauv. and V - Vicia sepium L., Agrostis tenuis Sibth. Mosses were found only near tree trunks; their cover was negligible.

The stand of Site 2 was composed of seven tree species that formed two layers with a total crown density of 0.4-0.5. B. pendula dominated in the first layer. Po. tremula and Pin. sylvestris were found less often. The average height of the trees reached $13.8 \mathrm{~m}$ (vary- ing from 12 to $16 \mathrm{~m}$ ), and the average trunk diameter was $11.5 \mathrm{~cm}$ (varying from 7.0 to $20.0 \mathrm{~cm}$ ). The second layer, 4.5-10.5 m high, was formed by Salix cinerea L. and Salix caprea L., as well as by single individuals of B. pubescens, Pin. sylvestris and Pic. obovata, with an average diameter of $4.5 \mathrm{~cm}$ (varying from 3.0 to $6.0 \mathrm{~cm}$ ).

The composition of the stand of Site 2 was the following: B. pendula (52\%), Po. tremula (17\%), Sa. cinerea (11\%), B. pubescens (7\%), Pin. sylvestris (7\%), Sa. caprea (4\%) and Pic. obovata (2\%). The share of hardwood trees and coniferous in the composition of woody species was $91 \%$ and $9 \%$, respectively. Abundant young growth and self-sown Po. tremula, Pin. sylvestris, $B$. pendula, and other species that were few in number were marked in the site. There were single individuals of Pic. obovata up to $1.5 \mathrm{~m}$ high. The total number of young growth and self-sown was 2700 individuals per hectare; B. pendula and Pin. sylvestris prevailed in the young growth (Fig. 2).

Salix pentandra L. and Sa. myrsinifolia Salisb. $(\mathrm{h}=2.5 \mathrm{~m})$ prevailed in the shrub layer; self-sown $S o$. aucuparia, Pad. avium and $V$. opulus $(\mathrm{h}=0.1-0.6 \mathrm{~m})$ were also found. The total projective cover of the shrub layer was $25 \%-30 \%$.

There were 24 species in the ground cover of Site 2 community; the total projective cover of the herb-shrub layer was $30 \%$ (varying from $15 \%$ to $50 \%$ ). The following undershrubs and semi-shrubs were identified: $\mathrm{Chi}$ maphila umbellata (L.) W.P.C. Barton (II) and Orthilia secunda (L.) House (IV). Poa pratensis (VII), Pyrola rotundifolia L. (VI), Calamagrostis epigeios (L.) Roth, Pyrola minor, Am. repens and Equisetum pratense Ehrh. (V) prevailed among the herbs. Mosses were found only near tree trunks; their cover was insignificant.

Site 3 was characterised by the two-layer stand with a crown density varying from 0.4 to 0.5 . B. pendula dominated, while Po. tremula had a single occurrence in the first layer. Average height of the trees was $14.5 \mathrm{~m}$ (ranging from 12.5 to $17 \mathrm{~m}$ ) and the average diameter was $12.8 \mathrm{~cm}$ (ranging from 9.0 to $19.0 \mathrm{~cm}$ ). The second layer was represented by $B$. pubescens, Sa. cinerea, Sa. caprea and Pin. sylvestris, which had a height from 4 to $12 \mathrm{~m}$ and an average diameter of $5.5 \mathrm{~cm}$ (from 2.5 to $10.0 \mathrm{~cm}$ ).

The stand of Site 3 had the following composition: B. pendula (40\%), B. pubescens (25\%), Sa. cinerea (16\%), Sa. caprea (8\%), Pin. sylvestris (8\%) and 
Po. tremula (3\%). The young growth and the self-sown B. pubescens, B. pendula and Po. tremula were abundantly represented, and the young growth of Pin. sylvestris and Pic. obovata (height from 0.1 to $3.8 \mathrm{~m}$ ) was also found. The total number of plants was 2900 per ha; B. pubescens and B. pendula prevailed in the young growth (Fig. 2).

The shrub layer was not formed. Only single individuals of Sa. myrsinifolia, Alnus incana (L.) Moench., So. aucuparia, Pad. avium and $V$. opulus were found; self-seeding height was $0.1-0.6 \mathrm{~m}$.

The herb-shrub layer of Site 3 was represented by 29 species. Projective cover varied from $15 \%$ to $55 \%$, with an average of $30 \%$. The following undershrubs and semi-shrubs were identified: $C h$. umbellata (II) and $O$. secunda (III). The herb species had the following constancy: VIII - Ca. epigeios, Pyr. minor; VI - Poa pratensis, D. cespitosa, Am. repens and IV - Pyr. rotundifolia. Moss cover was not formed.

Site Control 1 is located $3 \mathrm{~km}$ from the ash dump in a birch forest. The age of trees was $80-90$ years, and the density of the tree layer was $0.5-0.6$. The height of the first layer was 16-24 m and of the second layer was $5.5-12 \mathrm{~m}$. The first layer was formed by $B$. pendula with an average trunk diameter of $18.9 \mathrm{~cm}$ (from 14.0 to $26.0 \mathrm{~cm}$ ). The second layer consisted of B. pubescens, Po. tremula, Malus sylvestris Mill and, sporadically, Pin. sylvestris. Composition of Control 1 site stand was as follows: B. pendula (65\%), Po. tremula (15\%), B. pubescens (12\%), M. sylvestris (5\%) and Pin. sylvestris (3\%). The total share of deciduous was $97 \%$ and that of conifers was $3 \%$.

B. pendula and Pin. sylvestris prevailed in the young growth; single individuals of Pic. obovata of height from 1.0 to $3.0 \mathrm{~m}$ were noted (Fig. 2).

The shrub layer was formed weakly - its cover was not higher than $20 \%$. The following five species were found in this layer: So. aucuparia, Sa. caprea, Ch. ruthenicus, R. acicularis and Juniperus communis L.

Forty-seven species of plants were identified in the herb-shrub layer with a projective cover varying from $65 \%$ to $85 \%$ (in some places, up to $100 \%$ ). Vaccinium vitis-idaea L. and Vaccinium myrtillus L. were abundant among undershrubs. The following herb plants prevailed with high constancy: IX - Fragaria vesca; VIII - D. cespitosa, Veronica chamaedrys L.; VII - Veronica officinalis L.; VI - Ag. tenuis, Al. vulgaris;
V - Calamagrostis arundinacea (L.) Roth. The mosslichen layer was formed weakly.

Site Control 2 is located $7 \mathrm{~km}$ from the VTPS ash dump in a birch forest with an admixture of conifers. The age of the main forest-forming species (B. pendula) was 90-100 years (Tab. 1). The tree layer density was $0.4-0.6$. The upper layer, 16-25 m high, was formed by B. pendula trees with the average trunk diameter equal to $22 \mathrm{~cm}$ (from 14.5 to $30.0 \mathrm{~cm})$. The second layer $(6-12 \mathrm{~m}$ high) was formed mainly by coniferous species - Pin. sylvestris, Pic. obovata and Abies sibirica Ledeb., with an average diameter of $8.7 \mathrm{~cm}$ (ranging from $5.5-12.5 \mathrm{~cm}$ ). The stand composition of site Control 2 was the following: B. pendula (64\%), Pin. sylvestris (18\%), Pic. obovata (14\%) and $A b$. sibirica (4\%). The total share of hardwoods was $64 \%$ and that of conifers was $36 \%$.

Coniferous self-sown plants of Pin. sylvestris (18\%) and Pic. obovata predominated in the young growth; Po. tremula participated insignificantly. The height of individuals varied from 0.1 to $2-5 \mathrm{~m}$ (Fig. 2). The total number of young growth was 1200 individuals per hectare.

The shrub layer was formed by So. aucuparia, V. opulus, Lonicera xylosteum L., Sa. pentandra, R. acicularis and R. majalis, Cotoneaster lucidus Schltdl. and $C h$. ruthenicus. The projective cover of this layer was $25 \%-30 \%$.

Sixty plant species were identified in the herbshrub layer. Projective cover ranged from $85 \%$ to $90 \%$, reaching $100 \%$ in some places. $V$. myrtillus (III) was identified among undershrubs; $O$. secunda was found once among semi-shrubs. The following herb plant species prevailed: IX - Aegopodium podagraria L.; VIII - Galium boreale L., Brachypodium pinnatum (L.) Beauv, Rubus saxatilis L., Lathyrus vernus (L.) Bernh. and VII - Ca. arundinacea and F. vesca. The following forest tall herb species were found: Thalictrum minus L., Aconitum septentrionale Koelle, Lilium martagon L., Adenophora liliifolia (L.) A.D.C. and others. The moss-lichen layer was formed weakly.

Comparison of the studied forest communities of the VTPS ash dump showed that forest phytocoenoses with a predominance of broad-leaved tree species and a small admixture of coniferous species can form on the non-recultivated ash within 50 years. They differ from natural zonal forests in the size of trees as well as in the species diversity of the lower layers. 
Table 2. Ash particle size distribution

\begin{tabular}{|c|c|c|c|c|c|c|c|}
\hline \multirow{2}{*}{ Site } & \multicolumn{8}{|c|}{ Particle diameter $(\mathrm{mm}), \%$} \\
\cline { 2 - 9 } & $1.00-0.25$ & $0.25-0.05$ & $0.05-0.01$ & $0.01-0.005$ & $0.005-0.001$ & $<0.001$ & $<0.01$ \\
\hline 1 & 24.5 & 42.1 & 22.3 & 6.3 & 1.6 & 3.2 & 11.1 \\
\hline 2,3 & 8.5 & 56.5 & 23.6 & 4.2 & 4.6 & 2.6 & 11.4 \\
\hline
\end{tabular}

\section{Characteristics of substrate}

The initial ash of the VTPS had a silicate chemical composition $\left(\mathrm{SiO}_{2}-48.4 \%, \mathrm{Al}_{2} \mathrm{O}_{3}-23.4 \%, \mathrm{Fe}_{2} \mathrm{O}_{3}-14.2 \%\right.$, $\mathrm{CaO}-4.9 \%, \mathrm{MgO}-2.9 \%, \mathrm{SO}_{3}-3.8 \%$ ), contained mobile forms of $\mathrm{P}_{2} \mathrm{O}_{5}(23.5 \mathrm{mg} / 100 \mathrm{~g})$ and $\mathrm{K}_{2} \mathrm{O}(7.0 \mathrm{mg} / 100$ g) and was free from the exchangeable $\mathrm{Ca}^{2+}$ and $\mathrm{Mg}^{2+}$ (Chibrik et al. 2016).

Sand dominates mostly due to the fine sand fraction in the particle size distribution (Table 2) in the ash from a depth of 40 to $50 \mathrm{~cm}$ being weathered for 50 years. The proportion of clay is extremely small (nearly $11 \%$ ). In accordance with the soil classification, the ash can be classified as sandy loam, which is typical for fly ash substrate (Chibric et al. 2016).

The content of organic carbon due to the presence of unburned coal particles in weathered ash is about $0.8 \%$ in Site 1 and significantly more $(2.4 \%)$ in sites 2 and 3; nitrogen is present only in trace amounts (Tab. 3). Ash differs sharply in the reaction of the medium, which has alkaline values in Site 1 (8.23) and acidic values in the last two sites (6.54). This indicator is associated with a significantly lower content of absorbed calcium and magnesium cations $(9 \mathrm{mmol} / 100 \mathrm{~g}$ against $3 \mathrm{mmol} / 100 \mathrm{~g}$ ), as well as mobile forms of potassium (9 mg/100 g against $4 \mathrm{mg} / 100 \mathrm{~g}$ ) and a slightly lower content of mobile phosphorus $(24 \mathrm{mg} / 100 \mathrm{~g}$ against $16 \mathrm{mg} / 100 \mathrm{~g}$ ) in sites 2 and 3 .

Table 3. Chemical properties of ash

\begin{tabular}{|c|c|c|c|c|c|c|c|}
\hline $\begin{array}{c}\text { TOC, } \\
\%\end{array}$ & $\mathrm{~N}, \%$ & 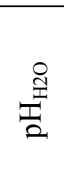 & 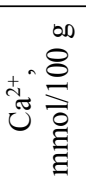 & 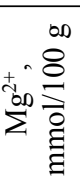 & 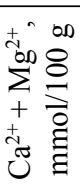 & 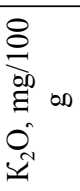 & 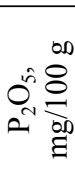 \\
\hline \multicolumn{8}{|c|}{ Site 1} \\
\hline 0.79 & nd* & 8.23 & 8.2 & 0.8 & 9.0 & 8.9 & 23.8 \\
\hline \multicolumn{8}{|c|}{ Sites 2 and 3} \\
\hline 2.42 & $\mathrm{nd}^{*}$ & 6.54 & 1.9 & 0.6 & 2.5 & 4.3 & 16.3 \\
\hline
\end{tabular}

nd* - not detected.
For 50 years, young soils have been formed at the VTPS ash dump under the forest community with the following set of morphologically expressed horizons: $\mathrm{O}-\mathrm{a}$ litter with a thickness of about $2 \mathrm{~cm}$ and $\mathrm{C}$ - a loose structureless ash substrate serving as a soilforming rock.

Analysis of the particle size distribution of the mineral part of the ash dump soils allowed detecting one more horizon differing in texture in all sites - AC - with a thickness of $5 \mathrm{~cm}$ (Tab. 4). While $\mathrm{C}$ horizons are characterised by a low content of physical clay and have a sandy loam texture, AC horizons contain considerably more particles with a diameter of $<0.01 \mathrm{~mm}$ and have a loamy texture.

Table 4. Soil particle size distribution

\begin{tabular}{|c|c|c|c|c|c|c|c|c|}
\hline \multirow[b]{2}{*}{ 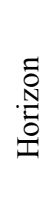 } & \multirow[b]{2}{*}{ 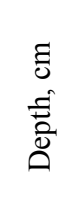 } & \multicolumn{7}{|c|}{ Particle diameter (mm), \% } \\
\hline & & $\begin{array}{l}\text { ñ } \\
\text { o } \\
1 \\
8 \\
0\end{array}$ & $\begin{array}{l}n \\
0 \\
0 \\
1 \\
n \\
n \\
0\end{array}$ & $\begin{array}{l}\overline{0} \\
\dot{0} \\
1 \\
\qquad \\
0 \\
\dot{0}\end{array}$ & $\begin{array}{l}n \\
8 \\
0 \\
0 \\
1 \\
0 \\
0 \\
0\end{array}$ & $\begin{array}{l}\overline{8} \\
0 \\
\dot{0} \\
1 \\
o \\
0 \\
0 \\
0\end{array}$ & $\begin{array}{l}\overline{8} \\
\dot{8} \\
\dot{\nabla}\end{array}$ & $\begin{array}{l}\overline{0} \\
\stackrel{0}{V}\end{array}$ \\
\hline \multicolumn{9}{|c|}{ Section 2} \\
\hline $\mathrm{AC}$ & $2-7$ & 0.7 & 58.2 & 17.3 & 6.0 & 8.9 & 6.5 & 21.4 \\
\hline $\mathrm{C}$ & $7-20$ & 5.5 & 71.8 & 10.0 & 2.8 & 4.0 & 4.0 & 10.9 \\
\hline \multicolumn{9}{|c|}{ Section 3} \\
\hline $\mathrm{AC}$ & $2-7$ & 0.80 & 33.3 & 24.9 & 15.7 & 15.3 & 8.1 & 39.0 \\
\hline $\mathrm{C}$ & $7-20$ & 0.02 & 74.2 & 10.8 & 4.4 & 5.2 & 3.6 & 13.2 \\
\hline
\end{tabular}

The $\mathrm{pH}$ values lay in the acidic range (6.4-6.9) in O horizons of the soils (Tab. 5), have minimum values in the profile in $\mathrm{AC}$ horizons, equal to 6.4 (Site 1) and 5.3-5.4 (sites 3, 4), and increase in horizon $\mathrm{C}$ to 5.9-7.3 in different sites. Soils of all studied sites of the forest community have a more acidic reaction of the medium in comparison with the corresponding weathered ash.

Regardless of the differences in the reaction of the medium, the maximum content of TOC (30-32\%), total $\mathrm{N}$ (1.7-1.9\%), mobile forms of potassium (130-180 $\mathrm{mg} / 100 \mathrm{~g})$ and phosphorus 
(7-10 mg/100 g), as well as exchangeable $\mathrm{Ca}^{2+}$ and $\mathrm{Mg}^{2+}$ (a total of $13-14 \mathrm{mg} / 100 \mathrm{~g}$ ) is clearly fixed in the litter of young soils at all sites. There is a decrease by an order of magnitude in the amount of TOC, total N, $\mathrm{K}_{2} \mathrm{O}$ and $\mathrm{P}_{2} \mathrm{O}_{5}$ with the depth of the profiles. Besides, a sharp decrease in the content of exchangeable $\mathrm{Ca}^{2+}$ and $\mathrm{Mg}^{2+}$ is observed as well in more acidic soils of sites 2 and 3.

Table 5. Chemical properties of soils

\begin{tabular}{|c|c|c|c|c|c|c|c|}
\hline 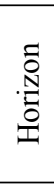 & $\begin{array}{c}\text { TOC, } \\
\%\end{array}$ & $\mathrm{~N}, \%$ & $\mathrm{pH}_{\mathrm{H} 2 \mathrm{O}}$ & 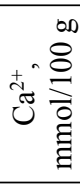 & 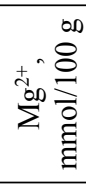 & 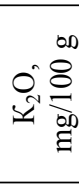 & $0^{n} \frac{0^{n}}{8} \frac{0}{8}$ \\
\hline \multicolumn{8}{|c|}{ Site 1} \\
\hline $\mathrm{O}$ & 31.84 & 1.79 & 6.87 & 11.5 & 3.6 & 138.0 & 6.7 \\
\hline $\mathrm{AC}$ & 2.47 & 0.13 & 6.42 & 3.7 & 2.0 & 21.7 & 0.1 \\
\hline $\mathrm{C}$ & 0.55 & 0.08 & 7.29 & 6.4 & 3.2 & 10.2 & 2.2 \\
\hline \multicolumn{8}{|c|}{ Site 2} \\
\hline $\mathrm{O}$ & 31.95 & 1.67 & 6.39 & 9.5 & 4.0 & 184.0 & 9.4 \\
\hline $\mathrm{AC}$ & 2.93 & 0.12 & 5.39 & 0.7 & 0.9 & 12.0 & 0.6 \\
\hline $\mathrm{C}$ & 2.23 & 0.10 & 5.92 & 0.7 & 0.4 & 9.5 & 1.9 \\
\hline \multicolumn{8}{|c|}{ Site 3} \\
\hline $\mathrm{O}$ & 30.69 & 1.87 & 6.39 & 9.6 & 3.7 & 127.8 & 10.1 \\
\hline $\mathrm{AC}$ & 2.23 & 0.16 & 5.33 & 0.6 & 1.0 & 13.5 & 1.6 \\
\hline $\mathrm{C}$ & 1.39 & 0.15 & 6.04 & 0.6 & 0.3 & 7.9 & 2.5 \\
\hline
\end{tabular}

\section{Discussion}

\section{Comparison of ash dump forest communities with zonal control ones}

The process of natural colonisation of pure ash is very slow since fresh ash is almost a sterile substrate and in the early years, no settlement of higher plants was noted (Tarchevsky 1964; Makhnev et al. 2002; Uzarowicz et al. 2017). Herbaceous species are often the pioneers of colonisation; the success of settlement of tree species depends on many factors -seed dispersal from adjacent forests, humidity and temperature regime of the substrate during the period of seeding the area, nature of the surface microrelief, sod formation by herbs, seeds and seedlings ablation by water, etc. (Chibrik and Elkin 1991; Drazic et al. 2007; Kaar and Kiviste 2010).
The results of the forest community study of the VTPS ash dump showed that forest phytocoenoses with a predominance of broad-leaved tree species and a small admixture of conifers have been formed on nonrecultivated ash.

The basis of the studied 35-40-year-old stands consisted of several deciduous trees: B. pendula, Po. trem$u l$ a, tree biomorphs of $S a$. cinerea and Sa. caprea and Pin. sylvestris from conifers. According to the type of population behaviour, the listed species belong to early succession species with a reactive (pioneer) strategy characterised by a long range of seed dispersal (Smirnova 2004).

The sparse canopy of B. pendula and Po. tremula young stands provides favourable conditions for the growth of self-sown species of late succession, and by the age of 20-30 years, Pic. obovata appears in the composition of tree species, as well as So. aucuparia, $V$. opulus and L. xylosteum in the young growth.

Colonisation of the ash dump by tree species is accompanied by an increase in their environment-forming function in proportion to productivity (Barannik et al. 2005). Fallen birch and aspen leaves decay rapidly, promoting a nutrient cycle and helping to maintain or increase the nutritional status of forest soils (Almgren 1990; Kaar and Kiviste 2010). Birch leaves contain large amounts of nitrogen, calcium, phosphorus and potassium; consequently, the litter in birch forests contains these nutrients, which leads to enriching the

Table 6. Biomorphological structure and species density of ash dump and zonal forest communities

\begin{tabular}{|l|c|c|c|c|c|}
\hline \multicolumn{1}{|c|}{$\begin{array}{c}\text { Charac- } \\
\text { teristic }\end{array}$} & \multicolumn{3}{|c|}{ Ash dump } & \multicolumn{2}{c|}{ Control } \\
\cline { 2 - 6 } & site 1 & site 2 & site 3 & control 1 & control 2 \\
\hline $\begin{array}{l}\text { total number } \\
\text { of vascular } \\
\text { plant spe- } \\
\text { cies, \% }\end{array}$ & 48 & 38 & 43 & 61 & 75 \\
\hline Trees & 10.4 & 18.4 & 16.3 & 9.8 & 6.7 \\
Shrubs & 12.5 & 13.2 & 11.6 & 8.2 & 10.7 \\
Undershrubs & - & 2.6 & 2.3 & 3.4 & 1.3 \\
Semi-shrubs & 2.1 & 2.6 & 2.3 & 1.6 & 1.3 \\
Herbs & 75.0 & 63.2 & 67.5 & 77.0 & 80.0 \\
\hline $\begin{array}{l}\text { Species den- } \\
\text { sity (number } \\
\text { of species } \\
\text { per 0.25 m }{ }^{2} /\end{array}$ & $8 / 3-14$ & $5 / 3-8$ & $7 / 4-11$ & $10 / 4-18$ & $14 / 6-19$ \\
min.-max.) & & & & & \\
\hline
\end{tabular}


soil with humus and improving its structure (Nikolaychenko 2005). In the soil under aspens, saturation by the bases of the humus horizon also increases (Frank and Borchgreving 1982).

Forest communities formed on the ash dump have a close species composition of the main forest-forming species, varying slightly in the participation of individual species' share, and are characterised by a relatively complex vertical structure. Po. tremula and $B$. pendula prevailed in the forest stand of Site 1 , and $B$. pendula and $B$. pubescens prevailed in sites 2 and 3. The plant communities of sites 2 and 3 had a more similar spatial structure of stands (number of layers, crown density) and a closer correlation of biomorphs (Tab. 6). The grass-shrub layer in all the studied ash sites was sparse, especially in Site 1.

In comparison with the control, the forest communities of the ash dump did not differ much in crown density, but their stand morphometric indicators (height and average diameter of trunks) were lower. The young growth layer was weakly expressed in forest communities both on ash and in control. The coverage of the herb-shrub layer was more than two times lower, and the species diversity of vascular plants was less in the ash dump sites than in the control ones.

An analysis of the species richness, taking into account the abundance of species (Fig. 3), revealed that this indicator in the studied forest communities of the ash dump was 1.6 times lower than in the control background communities. The forest phytocoenosis of Site

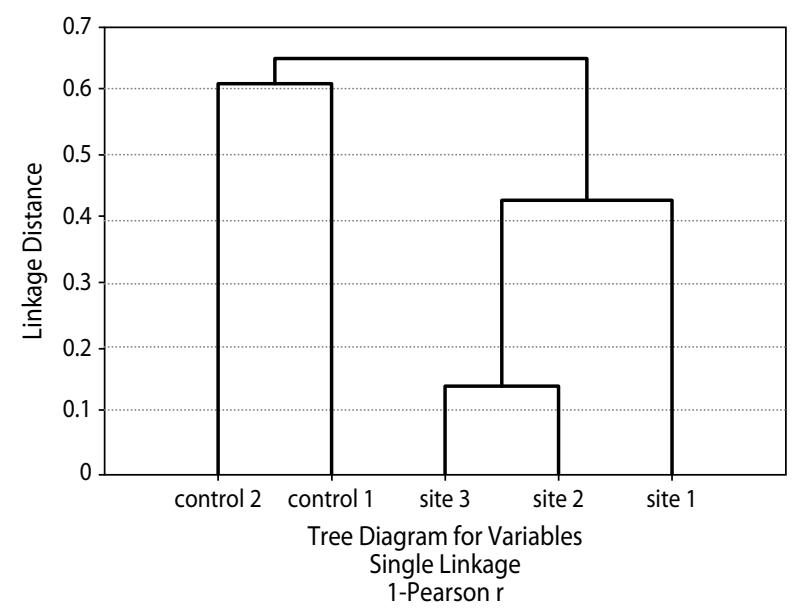

Figure 3. Comparison of the species composition of forest phytocoenoses, taking into account the abundance of species
1 differed in species composition from the phytocoenoses of sites 2 and 3 at the ash dump (Sorensen's coefficient of community similarity was 0.60 and 0.68 , respectively). At the same time, plant communities forming at sites 2 and 3 were more similar in terms of species composition - the Sorensen's coefficient was equal to 0.82 . Vegetation composition of forest phytocoenosis of ash dump Site 1 was the closest to that of control sites in natural forests (similarity coefficient of vegetation was 0.5 ). Sites 2 and 3 had lower coefficients of similarity with the control sites $(0.3$ and 0.4 , respectively), which may be due to the peculiarities of their ash substrate.

The species density of the grass-shrub layer of ash dump forest sites was lower than in the control, averaging 6.7 species (from 3 to 14 species) against 12 (from 4 to 19 species) in an area of $0.25 \mathrm{~m}^{2}$.

Moss-lichen cover in the ash dump forest was weakly expressed; 11 species of mosses were found, mainly on trees.

\section{Comparison of ash dump young soils and zonal soils}

Poorly differentiated soils with analytically identified horizons $\mathrm{O}, \mathrm{AC}$ and $\mathrm{C}$ had been formed at the VTPS ash dump in the southern taiga for half a century. They can be classified as Technosols (according to WRB 2014).

The loamy texture of $\mathrm{AC}$ horizons (while the ash and directly horizon $\mathrm{C}$ of the Technosols have the sandy composition) (Tab. 2 and 4) may be the result of the claying process in fine earth. Acidification of the medium has occurred in the Technosols of all sites compared to the weathered ash (Tab. 3 and 5).

The confinement of all considered elements to the maximum content in the litter (Tab. 3 and 5) means either their biogenic nature and accumulation in the process of the forest community formation or biogenic redistribution of ash elements over the soil profile. Thus, organic carbon and nitrogen (that was absent in substrate) were intensively stored in Technosols. The $\mathrm{Ca}^{2+}$ and $\mathrm{Mg}^{2+}$ exchange cations and the mobile forms of $\mathrm{K}_{2} \mathrm{O}$ and $\mathrm{P}_{2} \mathrm{O}_{5}$ presented in the weathered ash were redistributed with the depth. Potassium was the highest among all the elements that accumulated in the litter.

Soddy-podzolic soils (Egorov et al. 1977) or Retisols (WRB 2014) dominated in the forests around VTPS 
A
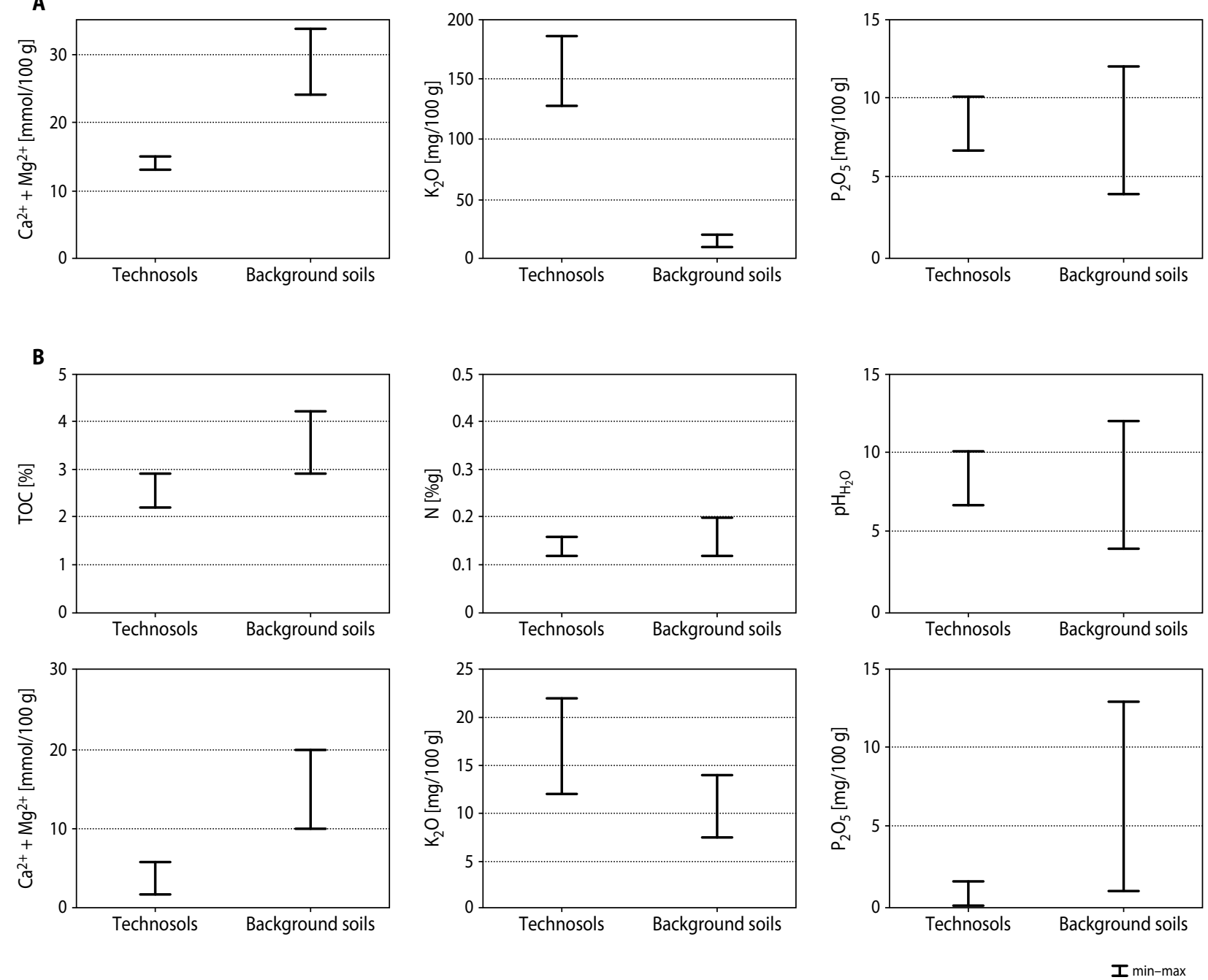

Figure 4. Limits of variation in chemical characteristics in the litter (A) and the humus horizons (B) of Technosols and background soils

ash dump. They had the following genetic horizons: O-A-E-B-BC-C (Gafurov 2008). The limits of variation of the studied Technosol upper horizon (O and $\mathrm{AC})$ characteristics and the corresponding horizons of background soils ( $\mathrm{O}$ and $\mathrm{A}$ ) were compared according to the literature (Firsova and Pavlova 1983; Gafurov 2008) and own materials.

The Technosols differed from background soils primarily in the levels of accumulation of the considered elements in $\mathrm{O}$ horizons (Fig. 4). The litter of young soils on the ash contained comparable amounts of TOC and mobile phosphorus, but had a less-acidic reaction of the medium, contained significantly more total $\mathrm{N}$, mobile potassium forms and much less absorbed $\mathrm{Ca}^{2+}$ and $\mathrm{Mg}^{2+}$.

The horizons of the compared soils under the litter - AC and A - had either partially or completely overlapping accumulation levels of the considered elements, with the exception of the content of absorbed cations that was much higher in the background soils.

It must be noted that the AC horizon of Technosols, on the one hand, was characterised by the formation of clay particles and some base nutrient accumulation like any humus horizon and, on the other hand, had the lowest $\mathrm{pH}$ values in the profile, which is typical for horizons E of background soils. 


\section{Conclusions}

In the process of natural colonisation of VTPS ash dump, mixed forest phytocoenoses have formed over 50 years, which are similar in composition to zonal secondary forests of southern taiga. Compared with the latter, they are characterised by a lower height and diameter of the trees, lower herb-shrub coverage, as well as lower species density and floristic richness. The revealed features of the composition and structure of the communities developed at the ash dump allowed us to evaluate these communities at the time of observation as a stage of progressive succession with improvement of conditions due to biotic transformation of the habitat (derivatives of the zonal type forests).

The process of soil formation in the ash substrate under the forest communities is also proceeding according to the zonal type: a litter was formed and the AC horizon combining the characteristics of humus and podzolic horizons was analytically distinguished. The formed Technosols are enriched with organic matter and basic nutrients.

The revealed features of the forest communities and young soils formed over 50 years on ash dump in southern taiga of the Middle Urals can be used to justify the forecasts of ecosystem restoration on the technogenic substrates in the studied area and in areas similar to it, as well as for the selection of species for their recultivation.

\section{Acknowledgement}

The work was supported by the Russian Foundation for Basic Research according to the research project No. 18-04-00714.

\section{RefERENCES}

Almgren, G. 1990. Broadleaued forest: birch, aspen and alder in forestry and nature conservation. Skogstyrelsen, Jonkoping, Sweden.

Arinushkina, E.V. 1970. Chemical soil analysis guide (in Russian). Moscow State University, Moscow, Russia.

Barannik, L.P., Shmonov, A.M. 2005. Recommendations on forest recultivation of disturbed by coal mining lands in Kuzbass. In: Recultivation of disturbed lands in Siberia: coll. of scient. papers (in Russian). Kemerovo, Russia, 124-145.

Chibrik, T.S. 2016. Biological Recultivation of Mine Industry Deserts: Facilitating the Formation of Phytocoenosis in the Middle Ural Region, Russia. In: Bioremediation and Bioeconomy (ed.: M.N.V. Prasad), Elsevier, 389-418. DOI: https://doi.org/10.1016/ B978-0-12-802830-8.00016-2

Chibrik, T.S., Elkin, Yu.A. 1991. Formation of phytocenoses on lands disturbed by industry: (biological recultivation) (in Russian). Ural University, Sverdlovsk, Russia.

Chu, L.M. 2008. Natural revegetation of coal fly ash in a highly saline disposal lagoon in Hong Kong. Applied Vegetation Science, 11, 297-306. DOI: https:// doi.org/10.3170/2008-7-18427

Drazic, D., Vassileva, I. 2007. Rehabilitation of landscapes degraded by stone, clay and sand opencast mining in Serbia and Bulgaria. In: Biological recultivation and monitoring of disturbed industrial lands, Ekaterinburg, Russia, 826-845.

Egorov, V.V. et al. 1977. Classification and diagnostics of soils of the USSR (in Russian). Kolos, Moscow.

Firsova, V.P., Pavlova, T.S. 1983. Soil conditions and features of the biological cycle of substances in mountain pine forests (in Russian). Nauka, Moscow, Russia.

Frank, J., Borchgrevink, I. 1982. Soil development under Norway spruce (Picea abies) and aspen (Populus tremula) stands at As. Meldinger fra Norges, Landbrukshogskole.

Gafurov, F.G. 2008. Soils of Sverdlovsk region (in Russian). Publishing House of the Ural State University, Ekaterinburg, Russia.

Gajic, G., Djurdjevic, L., Kostic, O., Jaric, S., Mitrovic, M., Pavlovic, P. 2018. Ecological potential of plants for phytoremediation and ecorestoration of fly ash deposits and mine wastes. Frontiers in Environmental Science, 6 (124), 1-24. DOI: https://doi. org $/ 10.3389 /$ fenvs.2018.00124

Jambhulkar, H., Juwarkar, A.A. 2009. Assessment of bioacumulation of heavy metals by different plant species grown on fly ash dump. Ecotoxicology and Environmental Safety, 72, 1122-1128. DOI: https:// doi.org/10.1016/j.ecoenv.2008.11.002 
Kaar, E., Kiviste, K. 2010. Mining and rehabilitation in Estonia. Estonian University of Life Sciences. Tartu, Estonia.

Makhnev, A.K. et al. 2002. Ecological principles and methods of biological reclamation of ash dumps of thermal power plants in the Urals (in Russian). Ekaterinburg, Russia.

Mitrovic, M. 2012. Photosynthetic efficiency of four woody species growing on fly ash deposits of a Serbian «Nikola Nesla - A» thermoelectric plant. Polish Journal of Environmental Studies, 21 (5), 1339-1347.

Mustafa, B., Hajdari, A., Krasniqi, F., Morina, I., Riesbeck, F., Sokoli, A. 2012. Vegetation of the ash dump of the "Kosova A" power plant and the slag dump of the "Ferronikeli" smelter in Kosovo. Environmental Earth Sciences, 4 (9), 823-834.

National atlas of Russia: Nature and ecology. 2008. Astrel, Roskartografia, Moskow. (in Russian with English summary).

Nikolaychenko, I.V. 2005. Features of natural forest growth of coal quarry rock dumps. In: Recultivation of disturbed lands in Siberia: coll. of scient. papers (in Russian). Kemerovo, Russia, 112-116.

Pandey, V.C., Singh, K., Singh, R.P., Singh, B. 2012. Naturally growing Saccharum munja L. on the fly ash lagoons: A potential ecological engineer for the revegetation and stabilization. Ecological Engineering, 40, 95-99.

Pandey, V.C., Prakash, P., Bajpai, O., Kumar, A., Singh, N. 2015. Phytodiversity on fly ash deposits: evaluation of naturally colonized species for sustainable phytorestoration. Environmental Science and Pollution Research, 22, 2776-2787. DOI: https://doi.org/10.1007/s11356-014-3517-0

Pandey, V.C. 2015. Assisted phytoremediation of fly ash dumps through naturally colonized plants. Ecological Engineering, 82, 1-5.

Pandey, V.C., Bajpai, O., Singh, N. 2016. Plant regeneration potential in fly ash ecosystem. Urban Forestry and Urban Greening, 15, 40-44. DOI: https://doi. org/10.1016/j.ufug.2015.11.007

Pandey, V.C., Singh, N. 2014. Fast green capping on coal fly ash basins through ecological engineering.
Ecological Engineering, 73, 671-675. DOI: https:// doi.org/10.1016/j.ecoleng.2014.09.036

Shaheen, S.M., Hooda, P.S., Tsadilas, C.D. 2014. Opportunities and challenges in the use of coal fly ash for soil improvements - A review. Journal of Environmental Management, 145, 249-267.

Shakirov, A.V. 2011. Physical-geographical Zoning of the Urals (in Russian with English summary). UB RAC, Ekaterinburg, Russia.

Smirnova, O.V. 2004. East European Forests: History in the Holocene and modernity (in Russian). Book 1. Nauka, Moscow.

Smith, T.M., Smith, R.L. 2012. Elements of ecology. Pearson, Harlow.

Tarchevsky, V.V. 1964. Biological methods of conservation of thermal power plants ash dumps of the Urals. In: Plants and industrial environment: coll. of scient. papers (in Russian). Ural State University, Sverdlovsk, Russia, 70-114.

Uzarowicz, L., Skibab, M., Leuec, M., Zagórskia, Z., Gąsińskid, A., Trzcińskie, J. 2018. Technogenic soils (Technosols) developed from fly ash and bottom ash from thermal power stations combusting bituminous coal and lignite. Part II. Mineral transformations and soil evolution. Catena, 162, 255-269. DOI: https://doi.org/10.1016/j.catena.2017.11.005

Uzarowicz, L. et al. 2017. Technogenic soils (Technosols) developed from fly ash and bottom ash from thermal power stations combusting bituminous coal and lignite. Part I. Properties, classification, and indicators of early pedogenesis. Catena, 157, 75-89. DOI: https://doi.org/10.1016/j.catena.2017.05.010

Vorobyova, L.A. 2006. Theory and practice of chemical analysis of soils (in Russian with English summary). GEOS, Moscow, Russia.

Weber, J. et al. 2015. Properties of soil materials derived from fly ash 11years after revegetation of post-mining excavation. Catena, 133, 250-254. DOI: https:// doi.org/10.1016/j.catena.2015.05.016

World Reference Base for Soil Resources. 2014. International soil system for naming soils and creating legends for soil maps. Food and Agriculture Organization of the United Nations, Rome, Italy. 